used for a variety of discrimination learning tasks, delayed alternation, delayed reaction, and locomotor activity measurement (Pinsker, 1966; Sledjeski \& French, 1968). S performance appears to be comparable to that found in a variety of WGTA apparati used in other laboratories.

\section{Cleaning and Disinfection}

The use of stainless steel and plastic throughout, and the easy accessibility of all parts of the apparatus allow rapid and complete cleaning. We customarily use a Wescodyne disinfectant solution for this purpose.

\section{REFERENCES}

DAVENPORT, J. W., CHAMOVE, A. S., \& HARLOW, H. F. The semiautomatic Wisconsin general test apparatus. Behavior Research Methods \& Instrumentation, 1970, 2, 135-138.

HARLOW, H. F., \& BROMER, J. A. A test apparatus for monkeys. Psychological Record, 1938, 19, 434-436.

HARLOW, H. F. The formation of learning sets. Psychological Review, 1949, 56, 51-65.

MEYER, D. R., TREICHLER, F. R., \& MEYER, P. M. Discrete-trial training techniques and stimulus variables. In $A$. M. Schrier, H. F. Harlow, and F. Stollnitz (Eds.), Behavior of nonhuman primates. New York: Academic Press, 1965. Pp. 1-49.

MCCONNELL, D., POLIDORA, V. J. FRIEDMAN, M. P., \& MEYER, D. $R$ Automatic reading and recording of digital data in the analysis of primate behavior I.R.E. Transactions (Medical Electronics), ME-6, 1959, 121-125.

PINSKER, H. M. Behavioral effects of dorsolateral, lateral orbital, and medial orbital lesions in frontal granular cortex of rhesus monkeys. Unpublished doctoral dissertation, University of California at Berkeley, 1966.

RIOPELLE, A. J. Facilities of the Emory University Primate Behavior Laboratory. Journal of Psychology, 1954, 38, 331-338.

SCHRIER, A. M. A modified version of the Wisconsin General Test Apparatus. Journal of Psychology, 1961, 52, 193-200.

SLEDJESKI, $M$., \& FRENCH, $G$. $M$. Multiple transfer paradigms following discrimination problem solution in monkeys. Journal of Comparative \& Physiological Psychology, 1968, 66, 228-231.

\section{ERRATA}

KLETSKY, EARL J. A six-channel PDP-8 interface for nerve impulse data. Behavior Research Methods \& Instrumentation, 1971, 3 (2), 85-87.The figure on p. 85 is not complete. A correct version appears at the right.

LEWIS, J. L., BOIS, S. J., \& OSGOOD, G. W. Zoroaster: A multiprogramming system for psychological research. Behavior Research Methods \& Instrumentation, $1971,3(2), 106-107 .-P .106$, col. 3, line 13, 1/2-sec should read 1/2-msec; line $17,100 \mathrm{msec}$ should read $100 \mu \mathrm{sec}$; p. 107, col. 2, paragraph 2, line 9, ITEME should read ITIME.

\section{CHANNEL PDP-8 INTERFACE \\ FOR \\ NERVE IMPULSE DATA}

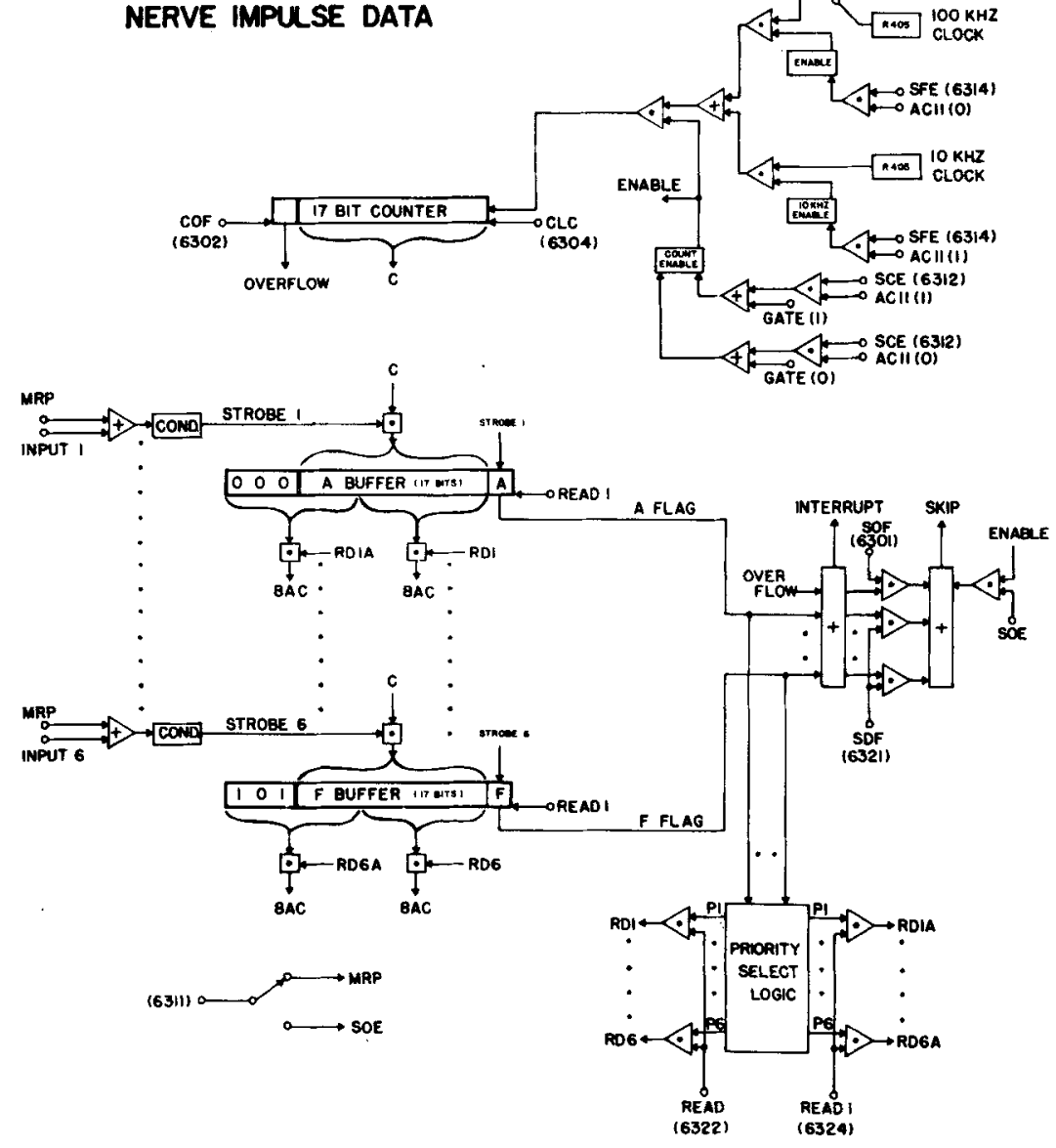

